Yayınlayan: Ankara Üniversitesi KASAUM

Adres: Kadın Sorunları Araştırma ve Uygulama Merkezi, Cebeci 06590 Ankara

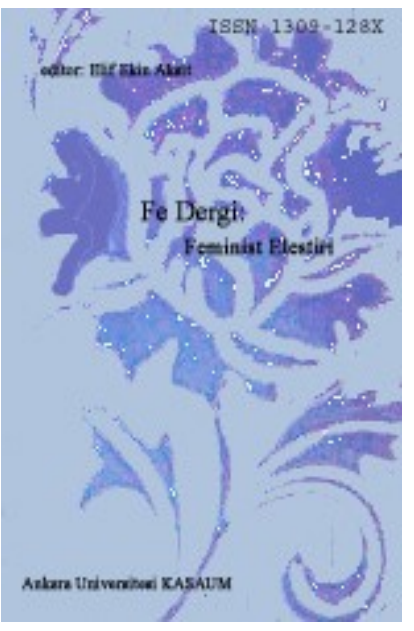

Fe Dergi: Feminist Eleştiri Cilt 5, Sayı 2

Erişim bilgileri, makale sunumu ve ayrıntılar için:

http://cins.ankara.edu.tr/

Nasıl Bir Barış Süreci: Geçiş Dönemi Adaleti ve

Toplumsal Cinsiyet

Mine Egbatan

Çevrimiçi yayına başlama tarihi: 24 Aralık 2013

Bu makaleyi alıntılamak için: Mine Egbatan, "Nasıl Bir Barış Süreci: Geçiş Dönemi Adaleti ve Toplumsal Cinsiyet" Fe Dergi 5, no. 2 (2013), 8-19.

URL: http://cins.ankara.edu.tr/10_3.html

$\mathrm{Bu}$ eser akademik faaliyetlerde ve referans verilerek kullanılabilir. Hiçbir şekilde izin alınmaksızın çoğaltılamaz. 


\title{
Nasıl Bir Barış Süreci: Geçiş Dönemi Adaleti ve Toplumsal Cinsiyet Mine Egbatan*
}

\begin{abstract}
Bu çalışmanın amacı, barış süreçlerinde başvurulan "geçiş dönemi adaleti” yaklaşımını kullanarak Türkiye'deki barış sürecine dair yeni bir tartışma alanı yaratmaktır. Geçiş dönemi adaleti, toplumsal cinsiyete duyarlı uygulamaları ve kadınların aktör olarak barış sürecine katılımını teşvik edici özelliği bakımından ele alınmaktadır. Kadınların sorunlarına duyarlı ve onların barış sürecine aktif katılımının sağlandı̆̆ örneklere yer verilerek toplumsal cinsiyete duyarlı bir geçiş dönemi adaleti mekanizmasının demokratik ve kapsayıcı toplumlar için rolü tartışllacaktır. Küresel sivil toplum aktörlerinin uygulamalarından bahsedilerek barış süreçlerinde yerel ve küresel aktörleri içeren anlayışın önemine değinilecektir. Bu bağlamda Barış İçin Kadın Girişimi’nin barışla ilgili talepleri ve çalışmalarına da yer verilecektir.

Anahtar sözcükler: kadınlar, barış, geçiş dönemi adaleti, küresel sivil toplum, çatışma
\end{abstract}

\section{How to Make Peace: Transitional Justice and Gender}

This paper is written to bring the issue of "transitional justice" as a site of discussion for peace process in Turkey. Transitional justice as an approach towards peace supports women's active participation in peace processes as well as develops an understanding that is responsive to women's problems based on conflict and/or war situations. Based on the examples of gender-responsive transitional justice processes, transitional justice mechanisms are important for creating democratic and inclusive societies and peace processes. Global civil society is an important actor in showing that transitional justice has an understanding of the interconnectedness between local and global. In this context, the initiatives and demands by Women's Initiative for Peace will be mentioned.

Keywords: women, peace, conflict, transitional justice, global civil society

\section{Giriş}

Türkiye'de otuz yıldan fazla bir süredir savaş ve çatışma durumu var. Kürt halkının demokratikleşme ve özgürleşme çabalarına karşın militarizmin, şiddetin, eşitsizliğin yeniden üretildiği bir ortamdan söz etmek mümkün. Böyle bir ortamdan en çok etkilenen de kadınlar oluyor. Zorla yerinden edilmeler sonucu erkeğe bağımlı hale gelme, ev içi şiddet, yoksulluk, eğitimsizlik, tecavüz gibi birçok sorunla karşı karşıya kalıyorlar. Savaşın erilliği ve şiddeti yücelten boyutu nedeniyle kadınların bu tür deneyimleri görünmez kılınıyor. Bu yüzden savaş koşullarının sona ermesi ve barış süreci, en çok da kadınları ilgilendiriyor. Geçtiğimiz mart ayından beri tartışılan barışın nasıl mümkün olacağı, barış sürecinde nasıl yol alınacağı, şiddeti ve eşitsizliği türlü boyutlarıyla yaşayan kadınlar için önemli bir konu. Kadınların barış tahayyülü sıcak çatışmanın bitmesinden daha da fazlasını kapsıyor: Daha eşitlikçi, demokratik ve özgürlükçü bir yaşama kavuşmak.

30 Eylül 2013 tarihinde AKP hükümeti tarafından açıklanan "Demokratikleşme Paketi”, barıș süreci ile ilgili kadınların isteklerine yönelik bir yanıt olabilir mi, barış sürecine ne gibi bir katkısı olacak soruları zihnimi meşgul ediyordu. Pakette barışın adı yoktu. Kadına dair tek şey ise başörtüsüyle ilgili düzenlemeydi. Esasen barış süreci ile ilgili tartışmalar başladığından beri barış görüşmelerinin başlıca aktörleri erkekler. Örneğin, barış sürecine katkısı olabilecek kişilerin bir araya getirildiği “Akil İnsanlar” projesinde 12 kadın, 51 erkek yer alıyor. Barış için Kadın Girişimi’nden Nazan Üstündağ böyle bir projenin meşruiyeti tartışılsa dahi kadınların eşit katılımının önemine işaret ediyor. ${ }^{1} \mathrm{Bu}$ durumda, kadınların barış ile ilgili görüşlerine önem verilmediğini söylemek mümkün.

Daha adil, demokratik ve uzlaşmacı bir barış süreci için yapılabileceklerin en başında kadınları bu sürece dâhil etmek ve onların ihtiyaçlarını, hak ve özgürlüklerini göz önünde bulundurmak gelir. Barış İçin Kadın Girişimi’nin pakete yönelik eleştirisinde de belirttiği gibi, "Barış süreçleri toplumun yeniden inşa edildiği ve yeni toplumsal sözleşmelerin ortaya çıktığı dönemlerdir". ${ }^{2} \mathrm{Bu}$ dönemlerde kadının güçlenmesi ve

"ODTÜ Kadın Çalışmaları Yüksek Lisans öğrencisi.

Yazının ilk halini okuyan ve detaylı yorumlarıyla bana yol gösteren Ayça Kurtoğlu’na ve deneyimlerini aktardığı için Ankara Barış için Kadın Girișimi’nden Gülsen Ülker’e teșekkür ederim. 
özgürleşmesi için yeni alanlar açılabilir ve kadın haklarına duyarlı bütünlüklü bir barış yaklaşımı geliştirilebilir. Bu bağlamda 1980'lerden beri dünyada örnekleri görülen "geçiş dönemi adaleti" yaklaşımı "Nasıl bir barış süreci?" sorusuna yanıt olabilir. Toplumsal cinsiyet adaleti (gender justice) meselesini de içeren geçiş dönemi adaleti tartışmaları, adalet ve barış anlayışııın kadınların deneyimlerine ve anlatılarına duyarlı olarak yeniden tanımlar. Ancak barışın kendi haline bırakıldığında erillikten kurtulamadığını düşünürsek, devletlerin ve hükümetlerin dışında, sivil toplum aktörlerinin perspektiflerine ihtiyaç vardır. Yine de sivil toplum aktörlerinin de zaman zaman eril bir perspektifle barışı değerlendirebileceğini göz ardı etmemek gerekir.

Bu çalışmada Türkiye'de henüz tartışılmaya başlanan bir konu olan "geçiş dönemi adaleti” yaklaşımını toplumsal cinsiyete duyarlı olması ve kadınların barış sürecine katılmasını teşvik edici özelliği bakımından ele alacağım. Geçiş dönemi adaleti yaklaşımının önemli aktörlerinden küresel sivil toplum örgütlerine odaklanarak dünyada barış süreçlerinin toplumsal cinsiyete duyarlı örneklerini göstermeye çalışacağım. Bunu yaparken Barış için Kadın Girişimi'ne de odaklanarak Türkiye'de barış süreci ile ilgili kadınların talepleri ve çabalarına da yer vereceğim.

\section{Geçiş dönemi adaleti ve küresel sivil toplum}

Geçiş dönemi adaleti yaklaşımının çalışma alanı, otoriter rejimlerden demokrasiye ya da çatışma süreçlerinden barış süreçlerine evrilen toplumlardır. Otoriter rejim ya da çatışma dönemlerindeki insan hakları ihlallerinin sorumlularını ortaya çıkarmaya, bu ihlallerin tekrar gerçekleşmemesi için gerekli önlemleri almaya ve mağdurların ihtiyaçları doğrultusunda barış ve demokrasiyi inşa etmeye yönelik bir yaklaşımdır. Toplumun, çatışmadan kaynaklanan yaralarını sarmak amacıyla oluşturulmuş çeşitli mekanizmalardan oluşur. $\mathrm{Bu}$ mekanizmalar cezalandırıcı (retributive), soruşturmacı ve onarıcı (restorative) yöntemler içerdikleri gibi, idari ve anayasal değişiklikleri de içerirler. ${ }^{3}$ Cezalandırıcı adalet yaklaşımı ulusal ve uluslararası mahkemeler gibi suçu işleyeni cezalandıran yasal mekanizmaları içerir. Onarıcı adalet yaklaşımı hakikat komisyonları gibi resmi olmayan süreçleri, maddi ve/veya sembolik tazminatları içerir ve diyalog yoluyla toplumsal barışı ve iyileşmeyi (healing) sağlamayı amaçlar. ${ }^{4}$ Hakikati arama, tazminatlar ve cezai prosedürler, çatışmasız ve insan hakları ihlallerinin yükü altında kalmayan, kapsayıcı bir toplum oluşturmak için kullanılırlar.

Geçiş dönemi adaleti yaklaşımı, yalnızca ne tür insan hakları ihlalleri yapıldığı, nerede ve nasıl yapıldığı üzerine yoğunlaşmaz. ${ }^{5} \mathrm{Bu}$ yaklaşımın önemi, bu tür ihlallere neden olan kurumsal yapıların ve toplumsal ilişkilerin dönüşmesine yönelik girişimlerinin olmasıdır. Politik temsilde eşitlik ve sosyoekonomik adaletsizliklerin giderilmesi için çabalar buna örnek gösterilebilir. Bütün bunlar Johan Galtung'un tanımladığı pozitif barışın inşası için önemlidir. Pozitif barış, yapısal ve kültürel şiddet ${ }^{6}$ unsurlarının ortadan kaldırıldığı bir toplumu tahayyül eder. ${ }^{7} \mathrm{Bu}$ anlamıyla geçiş dönemi adaletinin hem geriye hem de ileriye yönelik yaklaşımlar bütünü olduğunu söylemek yanlış olmaz.

Bu yaklaşımın uygulayıcıları yalnızca devletler değildir. Geçiş dönemi adaleti birçok aktörün katılımıyla daha verimli barış süreçlerinin ortaya çıkmasını sağlayabilir. Bu aktörlerden biri de sivil toplumdur. Sivil toplum, bireylerin kamusal alanda eylemde bulunmasını mümkün kılan çeşitli organizasyonlar ve gruplardan meydana gelir. ${ }^{8}$ Sivil toplumu, Jurgen Habermas' In kamusal alan görüşüne dayanarak “bilgiyi ve bakış açılarını iletmek amacıyla oluşturulan ağ” olarak anlıyorum. ${ }^{9}$ Jean L. Cohen, bu düşünceyi şu şekilde geliştirmektedir: "Sivil toplumun siyasi görevi demokratik örgütlenmeler ve çeşitli kültürel ve enformel kamusal alanlar aracılığıyla etki yaratmaktır". ${ }^{10}$ Dolayısıyla, toplumdaki farklı grupların görüş ve perspektiflerini ifade edebilmelerini sağlamak açısından sivil toplum önemlidir. Sivil toplum, devleti hakikat için harekete geçmeye zorlayarak "dokunulmazlık kültürü"nü "sorumluluk kültürü" ile değiştirmeye çabalamaktadır. ${ }^{11}$ Örneğin; Arjantin'de Plaza de Mayo Anneleri, hükümeti askeri cunta döneminde kaybolmuş insanlar hakkındaki hakikatleri açığa çıkarmaya zorlamışlardır. ${ }^{12}$ Hakikatlerin açığa çıkması, geçmişle hesaplaşılarak şiddetin ve insan hakları ihlallerine yol açan siyasal ve toplumsal ilişkilerin dönüştürülmesi için gereklidir. Türkiye'de de Barış ve Demokrasi Partisi (BDP) tarafindan hakikat komisyonu kurulması önerilmiştir. ${ }^{13} 1980$ 'lerden beri süregelen savaş nedeniyle yaşanan insan hakları ihlallerini, şiddeti ve eşitsizliği belgelemek, sorumluların ifşa edilmesi, yargılanması ve cezalandırılması için önemlidir. Ayrıca bu sürecin, geçmişte yapılan adaletsizliklerin tekrar yaşanmaması için dönüştürücü etkisinden de söz etmek mümkündür. ${ }^{14}$

Geçiş dönemi adaleti aktörlerinin çeşitliliği sayesinde, barış süreçlerinde isteksiz olan ya da sınırlı kaynaklarla barış inşa etmeye çalışan devletleri barış için motive etmeyi biraz daha kolaylaştırır. Yerel sivil toplumun söylemlerinin ve demokratik taleplerinin kolaylıkla göz ardı edilebildiği bir durumda küresel sivil toplum aktörleri önem kazanır. Küresel sivil toplumdan kasıt, geçiş dönemi adaletini destekleme konusunda 
adım atan tüm dış aktörlerdir. Bundan ötürü, küresel sivil toplum, Uluslararası Uyarı (International Alert) gibi yerel tabanlı olup küresel bazda hareket eden hükümet dışı sivil toplum kuruluşları olduğu kadar, Uluslararası Geçiş Dönemi Adaleti Merkezi (International Center for Transitional Justice-ICTJ) gibi dünyanın birçok ülkesinde üyesi bulunan küresel hükümet dışı sivil toplum kuruluşlarını da kapsar.

Küresel sivil toplum, geçiş dönemi adaleti konusunda iki ana role sahiptir: Yerel sivil toplum örgütlerinin çalışmalarını desteklemek ve geçiş dönemi adaleti mekanizmaları ile ilgili tartışmalarda bulunmak. Küresel sivil toplum, çatışmaların yaşandığı veya çatışma sonrası dönemlerden geçen devletlerdeki yerel sivil toplum kuruluşlarını destekler. Barış sürecinde rol oynamaya çalışan yerel sivil toplum kuruluşları zayıf ve dağınık olabilir; çatışma koşullarında halkları bir araya getirerek görüşlerinin alınacağı zeminlerin oluşması zor olabilir ya da ulusal kuruluşlar yerel sivil toplum örgütlerinin çalışmalarına kayıtsız olabilir. Bu noktada küresel sivil toplumun aktörleri, insan hakları ihlalleriyle ilgili soruşturmalar gerçekleştirirler ve insan haklarına uyulup uyulmadığını gözlemlerler. ${ }^{15}$

$\mathrm{Bu}$ alanda çalışmalar yürüten küresel sivil toplum aktörlerinden Uluslararası Geçiş Dönemi Adaleti Merkezi (ICTJ), geçiş dönemi adaleti ile ilgilenen bir grup hukukçu, insan hakları savunucusu ve aktivisti tarafından 2001 yılında New York merkezli olarak kuruldu. ${ }^{16}$ Otuzun üzerinde ülkede faaliyet gösteren ICTJ, geçiş dönemi adaleti konusunda yerel sivil toplum örgütlerine yardımcı oluyor. Örneğin; Burma'da, yerel sivil topluma uzmanlık bilgisi sunarak insan hakları ihlallerinin belgelenmesine yardım ediyor. Kıbrıs'tan ve Lübnan'dan mağdurları bir araya getirerek deneyimlerini paylaşmalarını sağlıyor. Yine, merkezi İngiltere'de olan Uluslararası Uyarı; Afrika, Asya ve Latin Amerika'daki yirmiye yakın ülkede barışın inşası için girişimlerde bulunuyor. Çatışmalı gruplar arasındaki diyaloğu teşvik edici çalışmalar yapıyor. ${ }^{17}$

Küresel bazda faaliyet gösteren sivil toplum örgütleri, insan hakları ihlalleri ile ilgili soruşturmalar gerçekleştirirler ve insan haklarına saygılı barış süreçleri için gözlemci olurlar. ${ }^{18}$ Uluslararası Af Örgütü (Amnesty International), cezai soruşturmaların gerçekleştirilmesini güvenceye almak amacıyla Eski Yugoslavya Uluslararası Ceza Mahkemesi'nin çalışmalarını gözlemlemiştir. ${ }^{19}$ Yerel barış süreçlerini destekleyerek bu süreçlerin uluslararası insan hakları normları çerçevesinde ele alınması gerektiğini vurgular. Bu şekilde yerel ve küresel değerleri bir potada eritmenin önemine işaret eder. 1961 yılında kurulan Uluslararası Af Örgütü bugün Türkiye dahil seksenin üzerinde ülkede faaliyet gösteriyor. Barış süreciyle ilgili açıklamalarda bulunan örgüt, barış sürecinin toplumsal dönüşüm süreci olduğunu ifade ediyor ve insan hakları ve özgürlüklerin korunması gerektiğini bildiriyor.

Küresel hukukun ve yargı sürecinin geliştirilmesi sırasında küresel sivil toplum inisiyatif alarak dünyadaki çeşitli aktörlerle etkileşime girmiştir. Bünyesinde 2.500 kuruluş bulunduran Uluslararası Ceza Mahkemesi Koalisyonu (The Coalition for ICC), kapsayıc bir Uluslararasi Ceza Mahkemesi (International Criminal Court) oluşturabilmek konusunda koordine edici bir role sahiptir. ${ }^{20}$ Küresel sivil toplum aktörlerine bakıldığında giderek küreselleşen bir yapıdan ve geçiş dönemi adaleti anlayışından söz etmek mümkündür.

İkinci olarak, küresel sivil toplum, geçiş dönemi adaleti sürecinde kullanılması göz önünde bulundurulan çeşitli mekanizmalarla ilgili tartışmalara katkıda bulunur. Cezalandırıcı adalet ya da dönüştürücü/onarıcı adalet anlayışının ayrı ayrı ya da bir arada kullanılabileceği durumlar konusunda tartışma zeminleri oluşturur. Toplumsal cinsiyet adaleti kavramını tartışmaya sokan ve geçiş dönemi adaleti yaklaşımının ayrılmaz bir parçası yapan küresel sivil toplum aktörleridir. Öyleyse, küresel sivil toplum, kapsayıcı bir geçiş dönemi adaleti süreci için önemli sonuçları olan geçiş dönemi adaleti söyleminin müzakere edildiği ve tartışıldığı bir arena olarak düşünülebilir ki bunun kapsayıcı bir geçiş dönemi adaleti süreci için son derece önemli sonuçları vardır. ${ }^{21}$

\section{Barış sürecine yeni özneler ve sorunlar dâhil etmek}

Küresel sivil toplum aktörleri, kadınların çatışma dönemindeki ihtiyaçlarını ve endişelerini dile getirebilecekleri yeni alanlar yaratırlar. Küresel toplum, bunu sağlayarak geçiş dönemi adaleti mekanizmalarına toplumsal cinsiyet boyutu eklemeye çabalar. Toplumsal cinsiyet adaleti, barış sürecinin önemli bir parçası olarak ele alınır. $\mathrm{Bu}$ çaba, daha demokratik ve kapsayıcı bir geçiş dönemi adaleti mekanizması yaratma konusunda önemli etkilere sahiptir. Küresel sivil toplum aktörleri, barış süreçlerinin erkek egemen yapısına karşı çıkarken toplumsal cinsiyet duyarlılığı olan bir toplum tahayyülü için çalışır.

Barış süreçlerinin toplumsal cinsiyet körü olduğu söylenebilir. Geleneksel toplumsal cinsiyet söylemleri barış süreçlerini şekillendirir. Savaşın özneleri erkekler, barışla ilgili çalışmaları ve söylemleri etkilemeye uğraşırlar. Christine Bell ve Catherine O’Rourke'nin belirttiği gibi, “Ayrımcılığın, tahakkümün, fiziksel, sosyal ve hukuksal güvenliğin özellikle toplumsal cinsiyet bağlamında iyileştirmesinin altında yatan meseleleri ele alan 
sorunlara çoğunlukla ikincil bir önem atfedilir ya da hiç edilmez".² Türkiye'deki barış sürecine baktığımızda barış görüşmelerinin erkek aktörler tarafından yürütüldüğünü görüyoruz. Barıştan bahseden erkekler kadınların acılarını, isteklerini ve eylemliliklerini göz ardı ediyor ve kamusal alanda görünür kılmaya yanaşmıyor. Kürt kadınların zorunlu göç deneyimi dolayısıyla yaşadıkları şiddet, ev içi zorlukların çözümü, taciz ve tecavüz deneyimleri tartışılmıyor. Handan Çağlayan, kadınların savaş dolayısıyla yaşadıklarına dair bildiklerimizin ne kadar yetersiz olduğuna vurgu yaparken kadınların savaş nedeniyle karşılaştığı dil ile ilgili baskı ve gözaltında cinsel şiddet gibi deneyimlerden bahsediyor. ${ }^{23}$ Kürtçe konuştuğu için yargılanan tutuklu annesi Saliha Şener, insan hakları ihlalleri ve gözaltında cinsel şiddet ile ilgili çalışmalar yapan avukat Eren Keskin, politikacı kimliğiyle tanınan Hatice Yaşar'ın yazılarından dolayı yargılanması, ${ }^{24}$ Kürt kadınlara yönelik ayrımcılığın görünen kısmı. Otuz yıllık savaşın tezahür ettiği coğrafyada kadınların maruz kaldıkları şiddet hakkında bir de görünmeyenler ve hiç konuşulmayanlar var. Handan Çağlayan, Şemsa Özar ve Ayşe Tepe Doğan'ın 'Ne Değişti?: Kürt Kadınlarının Zorunlu Göç Deneyimi” kitabı kadınların deneyimlerine ve tanıklıklarına başvurması bakımından önemli. Özellikle dil yüzünden ayrımcılığa uğrayan, işten çıkarılan, okula devam etmek istemeyen, eve kapanmak zorunda kalan kadınların tanıklıkları barışın inşası sürecinde yapılması gerekenlere dair fikir verebilir. ${ }^{25}$ Çağlayan'a göre toplumsal cinsiyet perspektifinden yoksun bir barış süreci, "kadınların marjinalleştirilmesini yeniden üretme potansiyeli taşıyacak" ${ }^{26} \mathrm{Bu}$ noktada geçiş dönemi adaleti yaklaşımı açısından şu durumlar önem kazanıyor: Kadınların savaş/çatışma koşullarından kaynaklanan sorunlarını dile getirip çözümler üretmek ve böylece kadınların barış sürecine eşit bir şekilde katılımını sağlamak.

Savaş/çatışma zamanlarında kadınlar cinsel şiddetten ciddi bir şekilde etkilenirler. Tecavüz bir savaş aracı olarak kullanılır. Kadın bedenini erkeğe ait gören anlayıştan kaynaklanan cinsel şiddet, savaş zamanı kadınların çokça karşı karşıya kaldığı bir durumdur. Örneğin, Demokratik Kongo Cumhuriyeti’ndeki savaş boyunca kadınlar hem Kongo ordusu hem de yabancı milis güçleri tarafindan tecavüze uğradılar. Guatemala'da, cinsel şiddet soykırımın bir aracı olarak kullanılmıştır. ${ }^{27}$ Buna rağmen kadınların bu deneyimini dillendirmesi toplumsal baskılar yüzünden zor oluyor. Örneğin, hakikat komisyonlarının raporlarında kadınların cinsel şiddet konusundaki deneyimleri geniş olarak anlatılmaz. Güney Afrika Hakikat ve Uzlaşma Komisyonu'nda, 22.000 tanıktan sadece 158 kadın olmak üzere toplumsal cinsiyete dayalı şiddetle ilgili tanıklık etmiştir. ${ }^{28}$ Hakikat komisyonlarının tespitlerinde erkek-merkezli hakikatlerin üstünlüğü vardır. Kadınlar hakikat komisyonlarında genellikler kocalarına, çocuklarına veya babalarına yapılan insan hakları ihlalleriyle ilgili tanıklık yaparlar. ${ }^{29}$ Cinsel suçlarla ilgili deneyimlerinden bahsetmezler. Bunun ardında daha geniş olan toplum tarafından dişlanma korkusu yatar. Çoğu Afrika geleneği savaş zamanlarında tecavüze uğrayan kadınları toplumdan dışlar. ${ }^{30}$ Çok sayıda kültürde utanç, tecavüz ile ilişkilendirilir. ${ }^{31}$ Adli sistem, çatışma zamanlarındaki cinsel suçlarla ilgili davaları kovuşturma konusunda isteksiz davranabilir. Örneğin, Sierra Leone'de, mahkemeden önce, cinsel suçlarla ilgili deneyimlerinden bahsetmesinler diye kadınların gözü korkutulmuştur. ${ }^{32}$

Küresel sivil toplum bu anlamda toplumsal cinsiyete dayalı şiddetin üzerindeki sessizliği kırar. Kadınlara, kendilerine karşı işlenen cinsel suçlarla ilgili konuşmaları konusunda cesaret verir. Kadın Mahkemeleri (The Courts of Women); El Taller (El Taller International) ve Kadının Insan Hakları Asya Konseyi (Asian Women's Human Rights Council-AWHRC) tarafından, çok sayıda ağ ve sivil toplum örgütünün desteğiyle kurulmuştur. ${ }^{33}$ Kadın Mahkemeleri, kadınların cinsel suçlar nedeniyle çektikleri çileleri anlatabilecekleri yeni bir politik alan sunuyor. Küresel Kadın Fonu (Global Fund for Women), kadınların cinsel suçlarla ilgili deneyimlerini anlatabilecekleri bir merkez açmayı hedefleyen Kolombiya merkezli Wayuu Kadınlarının Gücü (Wayuu Women's Power) adlı kuruluşu destekliyor. ${ }^{34}$ Kadınlar, çatışma döneminden doğan problemlerini ve ihtiyaçlarını anlatmaya başladıklarında, ardından adalet arayışı ve kendilerine karşı işlenmiş suçların tazmin edilmesini istemek gelecektir. Bu sebeple, Kadın Mahkemeleri, yerel kadınları adalet aramaları konusunda teşvik ediyor. $\mathrm{Bu}$ mahkemedeki tanıklıklar, ulusal veya küresel yasal kurumlarda tazminat ve onarım talep eden kadınlar lehinde kanıt olarak kullanılabilir. Tokyo Uluslararası Kadın Mahkemesi bu açıdan önemli bir örnek oluşturur. İkinci Dünya Savaşı sırasında Japon ordusu tarafından seks kölesi olarak çalıştırılan kadınların (comfort women) hak ve özgürlüklerinin hiçe sayılmasını ortadan kaldırmaya yönelik bir adli bir mekanizma oluşturulur. Bölgesel çapta etkin olan kadın sivil toplum kuruluşlarından Japon Askerleri Iç̧in Seks Köleliği Yaptırlan Kadınlar Kore Konseyi (The Korean Council for Women Drafted for Military Sexual Slavery), ${ }^{35}$ Kadının Insan Hakları İçin Asya Merkezi (the Asian Centre for Women's Human Rights) ${ }^{36}$ ile Savaş Zamanı Kadına Yönelik Şiddeti Önleme Ağl (Violence Against Women in War) ${ }^{37}$ önemli girişimlerde bulunmuş ve iki yıllık bir süreç boyunca kadınların tanıklıklarını toplamışlardır. Kadınların, deneyimlerinin yükünü mahkeme 
önünde tekrar tekrar yaşamaması için tanıklıklar videoya kaydedilmiştir. Mahkeme sonucu seks köleliği kavramıyla ilgili uluslararası hukuka katkılarda bulunulmuş ve insan hakları ihlalleri belgelenmiştir.

Cinsel şiddetle ilgili deneyimlerini anlatabilmeleri için gerekli zemin yaratılırken aynı zamanda bu süreçleri kolaylıkla atlatması için kadınlara psikososyal destek sağlanması da gereklidir. Guatemala ve Peru'da bölgesel bir sivil toplum kuruluşu olan Proje Danışmanlık Hizmetleri (Project Counselling Service), kadınlara psikososyal destek sağlayan kurumlar arasında. Bunu da Duggan et al'ın dediğine göre kadınların iyileşme sürecine katkıda bulunma adına yapıyorlar. ${ }^{38}$

Küresel sivil toplum kuruluşları, devletleri cinsel suçlar konusundaki gerçekleri açığa çıkarmaya zorlarken toplumsal cinsiyet temelli şiddetin diğer boyutlarını da önlemeye yönelik çalışmalar yaparlar. Şiddetin yeniden üretildiği şartları ortadan kaldırmak için devletleri, kadınlara yapılan ayrımcılığı ele alan politikalar yürütmeye zorlarlar.

ICTJ, yerel ve küresel aktörlerden oluşan ve Liberya Hakikat Komisyonu'na toplumsal cinsiyet politikaları oluşturma konusunda baskı yapan Toplumsal Cinsiyet Komitesi'nin (Gender Committee) çalışmalarına katıldı. ${ }^{39}$ Küresel sivil toplum, yasal sistemde değişiklikler önererek, bu değişikliklerin gerçekleşmesini sağlayarak ve toplumsal cinsiyete daha duyarlı onarım programları yaratarak da kadınların adalet için uğraşmalarını mümkün kılıyor. Bu sayede, Liberya Hakikat ve Uzlaşma Yasası sivil toplum örgütlerinin teşvikleriyle "kadınların, çocukların ve korunmasız grupların deneyimlerini ele almak ve toplumsal cinsiyete dayalı ihlallere bilhassa dikkat etmek için özel mekanizma ve prosedürler" konusunda dikkatli olacağını belirtmiş, kadınların tanıklıklarını kolaylaştırmak için özel tanık koruma programları uygulayacağını taahhüt etmiş, oturumların gizli olacağı ve kadınların istedikleri dillerde tanıklık yapabileceğine dair yasalar koymuştur.

Carter Merkezi (The Carter Center), adli sistemin cinsel suçlara daha etkili cevap vermesini sağlamak amacıyla "Hukukun Üstünlüğünü Güçlendirme ve Cezasız Kalmayla Savaşma" ("Strengthening the Rule of Law and Combating Impunity") adında bir proje yürütmüştür. ${ }^{40}$ Carter Merkezi, bu projeyi yerel uzmanlar, hükümet yetkilileri ve hâkimlerle birlikte toplumsal cinsiyete daha duyarlı kanunlar ve yargı sistemi oluşturmak amacıyla gerçekleştirdi.

Kadınların ihtiyaçlarını ele almak ve şiddete maruz kalmış kadınlara adalet sağlama konusunda onarım önemli bir yer tutuyor. Onarım (ya da tazminat programları) değişik türlerde reformları içeriyor. Mağdurlara maddi tazminat verilmesinin yanı sıra sağlık ve eğitim alanında çalışmalar ve resmi makamlardan gelen özür gibi uygulamalar mevcut. Onarımın, "mağdurların insan olduğunun ve yeni politik düzende eşit vatandaşlar olacağının kabulü" ${ }^{41}$ olduğunu söylemek mümkün. Küresel sivil siyaset, onarımların toplumsal cinsiyete duyarlı bir öze sahip olması için çalışıyor. Örneğin, Uluslararası Geçiş Dönemi Adaleti Merkezi'nin katkılarıyla Sierra Leone'de, toplumsal cinsiyete duyarlı bir onarım programı gerçekleştirmesi mümkün olabildi. ${ }^{42}$ Kadınlara sağlık ile ilgili hizmetler sunuldu, iş yaşamına katılabilmeleri için kadınlara yönelik beceri geliştirme eğitimleri verildi. Hakikat komisyonu, kadınların ihtiyaçlarının çeşitliliğine onarım programları ile vurgu yapmıştır. Barışın inşasının kadının güçlenmesi ve eşitliğinden bağımsız olamayacağı vurgusu, 26 ülkede çalışmalarda bulunan Hivos International tarafından da yapılıyor. ${ }^{43}$ Malawi'deki çocuk gelinler projesi buna örnektir. Yerel sivil toplum örgütleriyle işbirliği içinde olan Hivos International, kız çocuklarının büyük çoğunluğunun on sekiz yaşından önce evlendiğine işaret ederek bunun kadın erkek eşitliğine aykırı olduğunu ve toplumsal cinsiyet ayrımcı normları dönüştürmek için önlenmesi gerektiğini savunur. ${ }^{44}$ Barışın inşasının, kadının güçlenmesi ve eşitliğinden bağımsız olamayacağı vurgusu daha kapsayıcı barış süreçleri için önemlidir.

Küresel sivil toplum, kadınların kamusal alanı yeniden kazanmalarına olanak sağlıyor. Barış süreçlerine aktif olarak kadınların katılması ve bu konuda uluslararası anlaşmaların uygulanması konusunda sivil toplum aktörleri çaba gösteriyorlar. Küresel sivil toplum bu yerel gruplara uzmanlık desteği ve eğitim sağliyor. IsisWICCE (Isis-Women's International Cross Cultural Exchange) adlı sivil toplum örgütü, Uganda'daki kadın liderleri barış sürecine katkıda bulunabilmeleri için eğitiyor. ${ }^{45}$ ICTJ, Ortadoğu ve Kuzey Afrika (MENA) bölgelerinde atölyeler gerçekleştirerek yerel kadınların geçiş dönemi adaleti sürecini etkilemeleri için ihtiyaç duydukları bilgi birikimini oluşturmaya çalışıyor. ${ }^{46}$ Bütün bu çabaların sonucu hakikat komisyonlarında özel toplumsal cinsiyet birimleri kuruldu. Hakikat komisyonlarının oluşturulmasında kadın kotası uygulamaları başlatıldı. Timor-Leste Hakikat Komisyonu'nda artık \% 30 kadın kotası uygulanıyor. Kadınları barış süreçlerine dâhil etmeye isteksiz olan eril hükümetler nedeniyle küresel sivil toplumun bu çabaları önem kazanıyor. 
Dolayısıyla, barışın toplumsallaşması, erkek egemenliğinden arındırılması için kadınların görüşmelere katılması ve barışın aktörleri olarak yer alması gerekiyor.

$\mathrm{Bu}$ açıdan Birleşmiş Milletler Güvenlik Konseyi’nin 1325 sayılı kararı ${ }^{47}$ kadınların barışla ilgili görüşmelere katılımını destekleyen ve alınacak kararlarda aktif rolünün öneminden bahseden bir düzenleme olarak önemli bir başvuru kaynağı olarak görülebilir. Türkiye bu metne imza vermesine rağmen bugün barış görüşmelerinin birkaç erkeğin tahayyülü ve görüşleri etrafında şekillendiği söylenebilir. Oysa yıllardır kadınların barış talebinin olduğunu ve çeşitli yollarla bunu dile getirdiğini söylemek mümkün. Cumartesi Anneleri, kayıp çocukları için her cumartesi Taksim Galatasaray Meydanı'nda eylem yapıyorlar ve kayıplarının bulunması için iktidarı zorluyorlar. ${ }^{48}$ Çatışmada çocukları ölen ya da hâlihazırda "dağda" olan annelerin oluşturduğu Barış Anneleri inisiyatifi, "Ellerimizi tüm annelere uzatıyoruz, yaşadığımız acılardan yaşamın filizlenmesi için, uzatılan barış elinin tutulmasını, bir an önce kalıcı bir barışın sağlanmasını istiyoruz" ${ }^{49}$ diyerek barış için bir araya geliyorlar. ${ }^{50}$ Buraya bir şerh de düşmek gerek. Kadınların anlatılarının özneleri savaşta, gözaltında kaybettikleri çocukları, kendi kimlikleri ve bedenleriyle bu anlatılarda yer almıyorlar. Bu sebeple toplumsal cinsiyetlendirilmiş anlatıların eksik kaldığını söylemek olası. Kadınların kendi deneyimlerine de odaklanması gerekiyor. Bu noktada Eren Keskin'in Heidi Wedel ile birlikte 1997 yılında kurduğu Gözaltında Cinsel Taciz ve Tecavüze Karşı Hukuki Yardım Bürosu kadınlara yönelik cinsel şiddetle ilgili tanıklıkları toplaması ve hukuki süreçlerde kadınlara destek olması bakımından değerli bir girişim. ${ }^{51}$ Keskin, büroya 387 kadının başvurduğunu ancak gerçek sayının bunun çok üzerinde olduğunu söylüyor. ${ }^{52}$

Türkiye'de kadın odaklı bir barış süreci talebi olan Barış İ̧̧in Kadın Girişimi (BİKG) 2009'dan beri aktif olarak kadınların barışa dair taleplerini dile getirmek için çalışıyor. BİKG her ilde barış noktaları

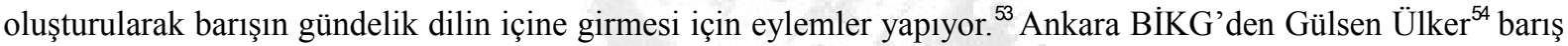
süreciyle ilgili tartışmaları şöyle aktarıyor:

Çatışmaların bitirilmesi, çekilme, yani bu son süreçte biz de daha kapsamlı çalışmaya başladık... Barış istediğimizi yıllardır dile getiriyoruz. Evet, barış oluyor, buyur dendiğinde ‘ee, ne yapacağız şimdi?” dedik. Bu aslında genel olarak Türkiye'deki durum. O yüzden diğer ülke deneyimlerine bakmaya başladık. Hani ne olmuş oralarda, nasıl bir süreç izlenmiş, kimler ne demiş. 1325 sayılı BM kararı aslında neredeyse bizim rehberimiz oldu. Ve diğer benzer süreçleri yaşamış ülke deneyimlerine ilişkin ağırlıklı olarak akademisyenler hem ziyaretler gerçekleştirdiler hem de yazılar yayınladılar. Bu deneyimlere baktık ve gördük ki aslında oralarda da aynı şey yaşanmış, kadınların gerçekten de neredeyse ayrı süreçler yürüttüğü örnekler var. Kadınların yürüttüğü süreçler genel müzakereler sekteye uğrasa bile sürüyor. İl bazında çalışmalar yürüyor, merkezi bir yapımız yok, her ilde Barış İçin Kadın Girişimi var. Biz Ankara'da atölye gerçekleştirdik sanıyorum Nisan ayında. Kapsamlı bir atölye oldu. Orada mesela birçok kadınla bir araya geldik, Kürt hareketi ve feminist hareket dışındaki kadınlara da ulaştık, özellikle Alevi çevreden kadınlara. ${ }^{55}$

Ülker, kadınlarla bir araya gelirken barışın inşasının sancılı bir süreç olduğunu anladıklarını ve barışı nasıl anlatacaklarına dair yollar bulma fikrinin oluştuğunu belirtiyor:

Orada (barışın) nasıl anlatılacağının aslında zor olduğunu gördük. Çatışmaların bitmesi herkes için sevindirici bir şey ama ona yüklenen anlam konusunda ayrışmaların yaşandığını gördük. Aynı zemini yakalamamızın zor olacağı konu alanları var. 30 yıllık bir çatışma var, aynı zamanda kemikleşmiş bir algı var ve bu nefret üreten bir algı aslında, onu yıkmanın zor olduğunu ama o yıkılmadan da sahiden bir barış ortamının çok olamayacağını, ben kendi adıma, öyle değerlendiriyorum. Bunun üzerine gidelim dedik, ama şu an yürüttüğümüz bir şey yok. Diğer illerde de bu tür karşılaşmalar yaşanıyor, yaşanacak.Biz,bubarışın toplumsallaşması denen şeyin ne kadar önemli olduğunu gördük. Buna çalışmamız lazım, ancak bunun yolu, yöntemi, dili üzerine çok düşünmemizgerekiyor...D1şlamadan,yok saymadan, küçümsemeden hem kendini anlatıp hem de onun acısını duyumsayarak bir dil geliştirmemiz gerekiyor. Atölyede bunu gördük... Bu süreç zor, profesyonel destek alınması gerektiğini gördük. ${ }^{56}$

Ülker, Barıș İçin Kadın Girişimi’nin barış inşası sürecindeki taleplerini şöyle yineliyor: 
Cinsel suçların cezasız kalmaması Barış İçin Kadın Girişimi’nin en net talebiydi. Öbür türlü olduğunda, şöyle bir şey yaşanmış örneğin Güney Afrika'da kadına yönelik şiddet tavan yapmış. Cezasız kalmaması gereken şeyler var, biz o yüzden kadınlar için hakikat komisyonlarının ayrı olmasını talep ettik. Özellikle gerilla kadınların geri dönüşlerine kadınların eşlik etmesini, kadın görevlilerle konuşmalarını, hâkimi, savcısı, güvenlikçisi, ne olacaksa, kadınlar için özel önlemleri talep ettik. ${ }^{5}$

Ülker, barış sürecindeki sivil toplumun çabalarının yanı sıra devletin kararlılık sahibi olmasının, barışın araçlarını sunması gerektiğinin, barışın önündeki engelleri kaldırmasının önemine değindi. Bu noktada küresel sivil toplumun inisiyatifi kadınları da kapsayan bir barışın inşası için gerekli olabilir. Bu düşüncemi Ülker ile paylaştığımda kendisi de uluslararası sivil toplum örgütleri ile bir bağ kurulması gerektiğini dile getirdi:

Kadınların bu uluslararası kuruluşlarla işbirliği geliştirmesi gerekiyor. 1325 sayılı karara göre ülke eylem planı olması gerekiyor sürece ilişkin. Bizim şu an öyle bir şeyimiz yok ama, biz nasıl kadına yönelik şiddetle mücadele ederken uluslararası belgeleri esas alıyoruz,o belgeler doğrultusunda hükümeti, devleti zorluyoruz, ona uyması için. Hem bunu yapmalıyız, hem o bağlamda da, bu bir BM metni, bununla ilgili diğer örgütlerle, kişilerle, gruplarla da işbirlikleri geliştirmemiz gerekiyor. Bizim buradaki çalışmalarımıza teknik destek de sağlamak için, mali destek de sağlamak için, böyle bir şeyi ben çok önemli buluyorum. Belki bizim gücümüz olsa, örneğin Ankara Barış İçin Kadın Girişimi olarak İç Anadolu’daki kadın örgütleriyle bir hafta, daha esnek zamanlı bir çalışma yapabilsek, dil ve söylem üzerine. Böyle karşılaşmaları organize etmemiz gerekiyor ki biz derdimizi anlatabilelim, onların da karşı çıkabilecek yeterince firsatları olsun... Daha uzun konuşma imkânımız olduğunda, daha ortak şeyler yapmak imkânımız olduğunda diyaloglar gelişebiliyor. Bu tür şeyleri yapabilmemiz lazım. ${ }^{58}$

Bu bağlamda, örneğin, The Global Network of Women Peacebuilders (Kadın Barış İnşacıları Küresel Ağı) ${ }^{59}$ yerel sivil toplum örgütleri ile işbirliği içinde BM'nin 1325 sayılı kararının uygulanıp uygulanmadığını denetler ve daha iyi uygulanabilirliği için farkındalık yaratmaya çalışır. Medyanın, BM'nin 1325 sayılı kararı ile ilgili haber yapma ve kadınların barış sürecine katılımı ile ilgili raporlar hazırlaması üzerine projeler yürütür. Bu uygulama barışla ilgili erkek egemen söylemlerin de ters yüz edilmesine yardımcı olan bir pratiktir. Dolayısıyla, küresel sivil toplumun kadınları bu sürece katma konusundaki çabası, geçiş hükümetlerinin demokratik doğasını geliştirebilir.

Küresel sivil toplum, kadınların kamusal alandaki yerinin korunarak daha katılımcı ve demokratik bir geçiş dönemi adaleti süreci yaratma rolüne sahip. Kadınların küresel sivil siyasetin katalizörlüğünde geçiş dönemi adaleti sürecine katılması, aynı zamanda sosyal yapıyı değiştirmeleri için gereken politik gücü de verecektir. ${ }^{\infty}$ Küresel sivil toplum, ataerkil yapılara meydan okuyarak uzun vadede kadın haklarının önemsendiği bir kültür oluşturmaya da katkıda bulunur. $\mathrm{Bu}$, daha katılımcı ve kapsayıcı bir geçiş dönemi adaleti süreci gerçekleştirme yolunda kritik bir girişim olarak görülebilir.

\section{Sonuç yerine}

Türkiye'de barış süreciyle ilgili tartışmalar kapsamında devlet tarafından atılan adımlara bakınca, yalnızca silahlı çatışmanın bitmesi ve gerillaların geri çekilmesi üzerine yoğunlaşma olduğunu söyleyebiliriz. Dolayısıyla açıklanan "Demokratikleşme Paketi" geçiş dönemi adaleti parametreleriyle ve toplumsal cinsiyet perspektifinden okunduğunda ortaya iç açıcı sonuçlar çıkmıyor. Savaş suçlarını ve insan hakları ihlallerini araştırmaya yönelik bir hakikat komisyonu kurulmasından ya da insan hakları ihlallerini önlemeye ilişkin yasal yaptırımlardan söz edilmiyor. Dünyadaki örneklere bakıldığında bu süreçlerde yer alması gereken kadınlarla ilgili bir düzenleme de söz konusu değil. Kadınların toplumsal cinsiyet temelli ayrımcılığa ve şiddete maruz kalması, kadın işsizliği, yoksulluğu, eğitimsizliği gibi sorunlara hiç değinilmiyor. Kadın gerillaların geri döndüklerinde karşılaşacakları sorunların çözümü ile ilgili bir yaklaşıma da yer verilmiyor. Hâlbuki barış için taraflardan biri de kadın gerillalar ve onların süreçle ilgili görüşlerinin alınması gerekiyor. Barış İçin Kadın Girişimi’nin bu yöndeki çabaları bir farkındalık yaratması bakımından önemli. ${ }^{61}$

Barış İçin Kadın Girişimi ve barışın kadın hak ve özgürlüklerine duyarlı olması için çalışan grupların çabalarının AKP hükümeti tarafından göz ardı edildiğini söylemek mümkün. Barışın yerel sivil toplumun 
müdahalelerine rağmen erillikten kurtulamadığı ve AKP hükümetinin dar bir barış vizyonunu hayata geçirmeye çalıştığı düşünüldüğünde küresel sivil toplum aktörlerinin tecrübelerinden faydalanmanın önemli olabileceğini düşünüyorum. Küresel sivil toplum örgütleri, deneyimleri ve birikimleriyle barış süreçlerinde yerel sivil toplum aktörleri ve devlet arasında bir bağ kurabilen üçüncü bir aktör işlevi görebilir. Kadınların barışın eyleyicileri olarak barış süreçlerinde yer almalarını desteklemeleri ve barış gündeminde kadınların sorunlarının ve ihtiyaçlarının yer almasını sağlamaları bakımından küresel sivil toplum aktörleri, geçiş dönemi adaleti süreçlerinin küresel boyutlarının da gerekli olduğunu gösteriyorlar. 
2 Barıș İçin Kadın Girișimi. "bikg ‘demokrasi paketi’ ile ilgili basın açıklaması yaptı”, http://www.barisicinkadinlar.com/baris/haber_detay.asp?haberID=498 (accessed 15 Ekim 2013)

3 Iavor Rangelov and Ruti Teitel, "Global Civil Society and Transitional Justice," Global Civil Society 2011: Globality and the Absence of Justice ed. Martin Albrow and Hakan Seckinelgin (Basingstoke, Palgrave Macmillan, 2011), 162.

Micheal J. Gilbert and Tanya L. Settles, “The next step: Indigenous development of neighborhood restorative community justice," Criminal Justice Review, 32 no. 5 (2007):7.

5 Nneoma Nwogu, "When and why it started: Deconstructing victim-centered truth commissions in the context of ethnicity-based conflict" International Journal of Transitional Justice 4 no. 2 (2010): 279.

6 Yapısal şiddet sınıf, toplumsal cinsiyet ya da etnisite bağlamındaki sosyal eşitsizliklere ve adaletsizliklere işaret eder. Daha ayrıntılı bilgi için, bkz. Johan Galtung, "Violence, Peace and Peace Research," Journal of Peace Research 6 no. 3 (1969): 167191. Kültürel şiddet ise yapısal ve doğrudan şiddeti (fiziksel şiddet gibi) meşru göstermeye yarayan pratiklerdir. Bkz. Johan Galtung, "Cultural Violence," Journal of Peace Research 27 no. 3. (1990): 291-305.

7 Johan Galtung, "Violence, Peace and Peace Research,” Journal of Peace Research 6 no. 3 (1969): 183.

8 Mary Kaldor, “The Idea of Global Civil Society" International Affairs 79 no. 3 (2003): 585.

9 Jurgen Habermas, Between Facts and Norms: Contributions to a Discourse Theory of Law and Democracy (Cambridge,Polity Press, 1996), 360.

10 Jean L. Cohen, "Interpreting Civil Society," Toward a Global Civil Society ed. Michael Walzer (New York: Bergham Books, 1995), 38.

11 David Crocker, “Transitional Justice and International Civil Society: Toward a Normative Framework” Constellations 5 no. 4 (1998): 503.

12 Margaret E. Burchianti, "Building Bridges of Memory: The Mothers of the Plaza de Mayo and the Cultural Politics of Maternal Memories," History and Anthropology 15 no. 2 (2004): 133.

14 Hakikat, Adalet, Hafiza Merkezi'nin hak ihlallerini ortaya çıkarmaya yönelik çalışmaları bulunuyor. http://www.hakikatadalethafiza.org/calismalarimiz.aspx?LngId=1 Zorla kaybedilenlerle ilgili oluşturulan veritabanı barış sürecinde oluşturulabilecek bir hakikat komisyonunun neleri göz önünde bulundurması gerektiğine dair başvuru kaynağı olarak kullanılabilir. http://www.zorlakaybetmeler.org/

15 Crocker, "Transitional Justice and International Civil Society," 510

${ }^{16}$ Hakikat, Adalet, Hafiza Merkezi, “Uluslararası STK'lar”, http://hafiza-merkezi.org/uluslararasi_stk.aspx?ContentId=81\&LngId=1 (accessed 2 Ekim 2013)

17

http://internationalalert.org/sv/ourwork/themes/peaceandeconomy

18 Crocker, "Transitional Justice and International Civil Society,"510.

19 Rangelov and Teitel, Global Civil Society and Transitional Justice," 168.

20 Rangelov and Teitel, Global Civil Society and Transitional Justice," 170.

${ }^{21}$ Rangelov and Teitel, Global Civil Society and Transitional Justice," 174.

22 Christine Bell and Catherine O’Rourke, "Does Feminism Need a Theory of Transitional Justice? An Introductory Essay,” The International Journal of Transitional Justice 1 (2007): 25.

23 Handan Çağlayan, Kürt Kadınların Penceresinden (İletişim Yayınları, 2013), 28.

${ }^{24}$ Çağlayan, Kürt Kadınların Penceresinden, 70, 72, 76.

25 Handan Çağlayan, Şemsa Özar ve Ayşe Tepe Doğan, "Ne Değişti?: Kürt Kadınların Zorunlu Göç Deneyimi," (İstanbul, Ayizi Yayınlar1, 2011)

${ }^{26}$ Çağlayan, Kürt Kadinların Penceresinden, 28.

27 Alison Crosby and M. Briton Lykes, "Mayan Women Survivors Speak: The Gendered Relations of Truth Telling in Postwar Guatemala," The International Journal of Transitional Justice 5 (2011): 461.

${ }^{28}$ Ketty Anyeko, "Mainstreaming Gender in Truth-seeking and Traditional Justice Processes in Uganda," Civil Society Dialogue on Gender and Transitional Justice in Uganda: Opportunities and Challenges (Summary Report, Gulu: Churcill Courts, 2011).

29 Vasuki Nesiah "Truth Commissions and Gender: Principles, Policies and Procedures," The International Center for Transitional Justice, Gender Justice Series (New York, 2006) http://ictj.org/sites/default/files/ICTJ-Global-Commissions-Gender-2006English 0.pdf

30 Cybele Cochran, “Transitional Justice: Responding to Victims of Wartime Sexual Violence in Africa," The Journal of International Policy Solutions 9 (2008): 33

31 Michelle Staggs Kelsall and Shanee Stepakoff, "When We Wanted to Talk About Rape: Silencing Sexual Violence at the Special Court for Sierra Leone," The International Journal of Transitional Justice 1 (2007): 362

32 Kelsall and Stepakoff "When We Wanted to Talk About Rape," 357.

33 El Taller International, "Courts of Women”, http://www.eltaller.in/?page id=73 (accessed 10 Temmuz 2013)

34 Global Women Fund, “Wayuu Women's Power”, http://www.globalfundforwomen.org/what-we-do/peace-a-gender-violence (accessed 12 Eylül 2013) 
ttp://www1.jca.apc.org/vaww-net-japan/english/aboutus/aboutus.htm

38 Colleen Duggan "Reparations for Sexual and Reproductive Violence: Prospects for Achieving Gender Justice in Guatemala and Peru," The International Journal of Transitional Justice (2008): 14.

39 ICTJ, “Transitional Issues: Gender Justice”, http://ictj.org/our-work/transitional-justice-issues/gender-justice (accessed 10 July 2013)

40 The Carter Center, “Carter Center Assists Liberia's Ministry of Justice in Strengthening Rule of Law”,http://www.cartercenter.org/news/features/p/conflict resolution/liberia strenghthen law.html (accessed 10 July 2013)

Ruth Rubio-Marín, What Happened to the Women?: Gender and Reparations for Human Rights Violations (New York, Social Science Research Council, 2006), 25.

42 Jamesina King, "Gender and Reparations in Sierra Leone: The Wounds of War Remain Open," What Happened to The Women?: Gender and Reparations for Human Rights Violations ed. Ruth Rubio-Marin (New York, Social Science Research Council, 2006), 260.

43 http://hivos.org/what-we-do

44 http://southern-africa.hivos.org/news/one-step-closer-ending-child-marriages-malawi

45 Harriet Nabukeera-Musoke, "Transitional Justice and Gender in Uganda: Making Peace, Failing Women During the Peace Negotiation Process," African Journal on Conflict Resolution 9 no. 2 (2009): 127.

46 ICTJ, "Transitional Issues: Gender Justice" (accessed 10 July 2013)

47 http://insanhaklarimerkezi.bilgi.edu.tr/Books/khuku/insancil hukuk baglaminda kadinlara yonelik cinsel siddet/insancil hukuk baglaminda cinsel siddet 1325-2000 sayili bm .pdf

48 Çă̆layan, Kürt Kadınların Penceresinden, 19.

49 http://www.bukak.boun.edu.tr/?p=789

50 Barış İçin Kadın Girişimi’nden Gülsen Ülker, kadınları annelik rolüne hapsetme konusunda eleştirel bir bakıș açısını tutmakla birlikte anneliğin bir ortaklık yarattığını ve barış için firsatlar oluşturabileceğini de unutmamak gerektiğini de belirtiyor: "Barış sürecinde kadınlar daha çok annelik üzerinden konumlanıyorlar. Hani evladını kaybetmiş. Feminizmin anneliğe ciddi eleştirileri var. Bu benim kişisel görüşüm ama orada da (atölyede) dile getirdim. Anneliğe bir daha bakmamız lazım... Anneliğe hapsedilme eleştirimiz baki ama buradaki annelik durumu önümüzü de açan bir şey olabilir. Çünkü kadınlar onun üzerinden ilişkileniyorlar... Anneliğe eleştirel bakabiliriz ama bu süreçlerde başka bir yerden bakabilmeyi becerebilmemiz de gerekiyor."

51 http://www.bukak.boun.edu.tr/?p=563

52 http://www.bianet.org/biamag/kadin/151717-eren-keskin-makyaj-yapmaya-nasil-basladim

53 Kişisel görüșme, 09.12.2013, Ankara

54 Ankara Barış İçin Kadın Girişimi’nden yalnızca Gülsen Ülker ile görüşme firsatım oldu.

55 Kişisel görüşme, 09.12.2013, Ankara

56 Kişisel görüşme, 09.12.2013, Ankara

57 Kişisel görüşme, 09.12.2013, Ankara

58 Kişisel görüşme, 09.12.2013, Ankara

59 http://www.gnwp.org/

60 Valerie Couillard, "The Nairobi Declaration: Redefining Reparations for Women Victims of Sexual Violence", The International Journal of Transitional Justice 1 (2007): 451.

61 http://www.barisicinkadinlar.com/baris/haber detay.asp?haberID=493. Reha Erdem'in "Jin" filmi aslında gerilla kadınların karşılaşacakları sorunları anlatması bakımından farkındalık yaratabilecek bir film. Bkz. http://www.bianet.org/bianet/siyaset/150323-demokrasi-paketi-ile-jin-i-hatirlamak 


\section{Kaynakça}

Anyeko, Ketty. "Mainstreaming Gender in Truth-seeking and Traditional Justice Processes in Uganda," Civil Society Dialogue on Gender and Transitional Justice in Uganda: Opportunities and Challenges (Summary Report, Gulu: Churcill Courts, 2011)

Bell, Christine and Catherine O'Rourke."Does Feminism Need a Theory of Transitional Justice? An Introductory Essay,” The International Journal of Transitional Justice 1 (2007): 23-44.

Burchianti, Margaret E. "Building Bridges of Memory: The Mothers of the Plaza de Mayo and the Cultural Politics of Maternal Memories," History and Anthropology 15 no. 2 (2004): 133-150.

Campbell-Nelson, Karen. "Liberia is Not Just a Man Thing," Transitional Justice Lessons for Women, Peace and Security, (The I International Center for Transitional Justice, 2008)

Cochran, Cybele. "Transitional Justice: Responding to Victims of Wartime Sexual Violence in Africa," The Journal of International Policy Solutions 9 (2008): 33-39.

Couillard, Valerie. "The Nairobi Declaration: Redefining Reparations for Women Victims of Sexual Violence", The International Journal of Transitional Justice 1 (2007): 444-453.

Crocker, David. "Transitional Justice and International Civil Society: Toward a Normative Framework” Constellations 5 no. 4 (1998): 492-517.

Crosby, Alison and M. Briton Lykes. "Mayan Women Survivors Speak: The Gendered Relations of Truth Telling in Postwar Guatemala," The International Journal of Transitional Justice 5 (2011): 456-476.

Çağlayan, Handan Kürt Kadınların Penceresinden (İstanbul, İletişim Yayınları, 2013).

Duggan, Colleen. "Reparations for Sexual and Reproductive Violence: Prospects for Achieving Gender Justice in Guatemala and Peru," The International Journal of Transitional Justice (2008): 1-19.

El-Bushra, Judy. “Feminism, Gender, and Women’s Peace Activism”, Development and Change 38 no.1 (2007): 131-147.

El Taller International, “Courts of Women”, http://www.eltaller.in/?page id=73

Forst, Rainer. “Towards a Critical Theory of Transitional Justice,” Metaphilosophy 32 no. 1-2 (2009): 160-179.

Gilbert, Micheal .J and Tanya L. Settles. “The next step: Indigenous development of neighborhood restorative community justice,” Criminal Justice Review, 32 no. 5 (2007): 5-25.

Global Women Fund, "Wayuu Women's Power, Colombia", http://www.globalfundforwomen.org/impact/success-stories/62/1267-wayuu-womens-power-colombia

Habermas, Jurgen. Between Facts and Norms: Contributions to a Discourse Theory of Law and Democracy (Cambridge, Polity Press, 1996)

ICTJ, "Vision and Mission", http://icti.org/about/vision-and-mission

ICTJ, "Regions and Countries: Burma", http://ictj.org/our-work/regions-and-countries/burmamyanmar

ICTJ, "Regions and Countries: Cyprus", http://ictj.org/our-work/regions-and-countries/cyprus>

ICTJ, “Transitional Issues: Gender Justice”, http://ictj.org/our-work/transitional-justice-issues/gender-justice

International Alert, “About Us”, http://www.international-alert.org/about-us

Kaldor, Mary. "The Idea of Global Civil Society” International Affairs 79 no. 3 (2003): 583-593.

Kelsall, Michelle S. and Shanee Stepakoff, "When We Wanted to Talk About Rape: Silencing Sexual Violence at the Special Court for Sierra Leone," The International Journal of Transitional Justice 1 (2007): 355-374.

King, Jamesina. "Gender and Reparations in Sierra Leone: The Wounds of War Remain Open," What Happened to The Women?: Gender and Reparations for Human Rights Violations ed. Ruth Rubio-Marin (New York, Social Science Research Council, 2006)

Nabukeera-Musoke, Harriet. "Transitional Justice and Gender in Uganda: Making Peace, Failing Women During the Peace Negotiation Process," African Journal on Conflict Resolution 9 no. 2 (2009): 121-129. 
Nesiah, Vasuki. "Truth Commissions and Gender: Principles, Policies and Procedures," The International Center for Transitional Justice, Gender Justice Series (New York, 2006), http://ictj.org/sites/default/files/ICTJ-Global-Commissions-Gender-2006-English 0.pdf

Rangelov, Iavor and Ruti Teitel, "Global Civil Society and Transitional Justice," Global Civil Society 2011: Globality and the Absence of Justice ed. Martin Albrow and Hakan Seckinelgin (Basingstoke, Palgrave Macmillan, 2011)

Rubio-Marín, Ruth. What Happened to the Women?: Gender and Reparations for Human Rights Violations (New York, Social Science Research Council, 2006)

Scully, Pamela. "Should We Give Up on The State? Feminist Theory, African Gender History and Transitional Justice," African Journal on Conflict Resolution 9 no. 2 (2009): 29- 42.

Teitel, Ruti. Transitional Justice (New York, Oxford University Press, 2000)

The Carter Center, "Carter Center Assists Liberia's Ministry of Justice in Strengthening Rule of Law", http://www.cartercenter.org/news/features/p/conflict_resolution/liberia_strenghthen_law.html

UN Security Council Resolution 1325 Women, Peace and Security (2000), http://www.un.org/events/res 1325e.pdf 